\title{
EPFL
}

COVID-19:

Insights from

Innovation

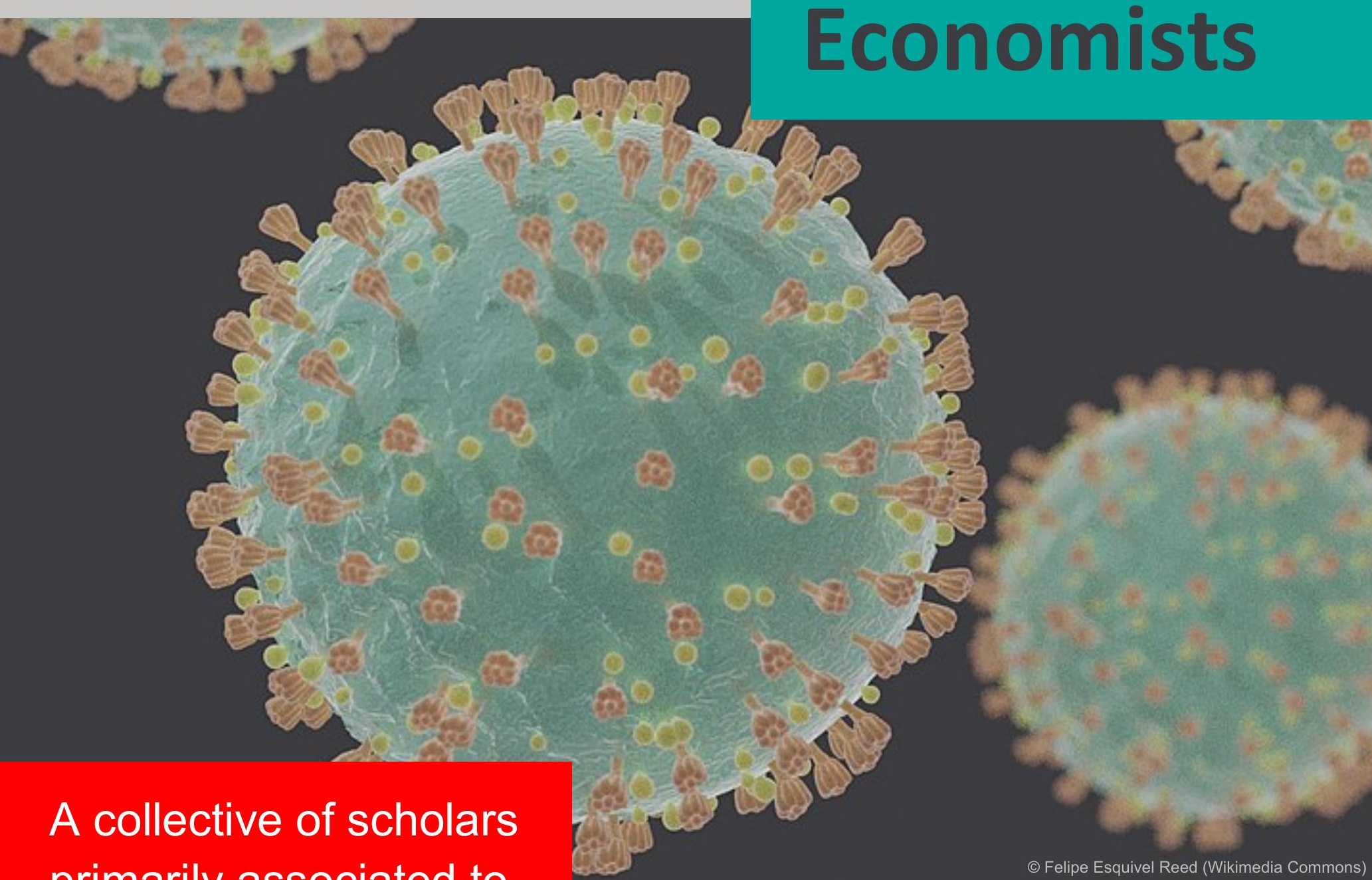
primarily associated to the College of Management of Technology at Ecole polytechnique fédérale de Lausanne 


\title{
COVID-19: Insights from Innovation Economists
}

\author{
A collective of scholars primarily associated to \\ the College of Management of Technology at \\ Ecole polytechnique fédérale de Lausanne
}

\author{
CDM members \\ PhD students: George Abi Younes \\ Charles Ayoubi \\ Omar Ballester \\ Gabriele Cristelli \\ Matthias van den Heuvel \\ Ling Zhou \\ Postdoc: Gabriele Pellegrino \\ Professors: Gaétan de Rassenfosse (gaetan.derassenfosse@epfl.ch) \\ Dominique Foray (dominique.foray@epfl.ch)
}

\section{External contributors}

Prof. Patrick Gaulé, University of Bath, Bath BA2 7AY, United Kingdom

Prof. Elizabeth Webster, Swinburne University of Technology, Hawthorn VIC 3122, Australia

Media enquiries: dominique.foray@epfl.ch and gaetan.derassenfosse@epfl.ch 


\section{Executive Summary}

The present document provides the take of innovation economists on the current pandemic. It is addressed to the general public and focuses on questions related to the Science, Technology, and Innovation (STI) ecosystem. It does not present new research findings. Instead, it provides a reading of current real-world developments using economic reasoning and relying on existing economic research.

The first part of the report explains the root causes for a general underinvestment in Research and Development (R\&D), with a particular focus on vaccines. These causes include an insufficient demand for vaccines in normal times and the very characteristics of R\&D. Governments can intervene to mitigate these problems, but government intervention comes with its own set of issues. We discuss three of them, namely free riding, setting research priorities, and acting on scientific knowledge.

The second part discusses several aspects related to current STI policy reactions. First, we observe a sizable shift of funds towards research on SARS-CoV-2. Aren't we wasting money by allocating so much of it on one single scientific problem? Using the concept of the 'elasticity of science,' we argue that we are far from a situation where additional funding would represent a waste of money.

Second, we also observe an unprecedented level of cooperation among researchers but also an intense competition to find therapeutic solutions and vaccines. We seek to make sense of this apparent antonymy, highlighting how both cooperative and competitive forces might accelerate research.

Third, we focus on one policy tool, namely patents, and we discuss whether the existence of patents hampers the search for a solution. We argue that it might, but we provide ways in which patents can be beneficial. They can accelerate research (such as through patent pools) or ensure greater access to innovations (such as with compulsory licensing).

Fourth, we notice that the whole STI ecosystem has been rapidly refocusing on SARS-CoV-2 in a way similar to mission-oriented R\&D (MOR) programs such as the Manhattan Project in the 1940s. We highlight the fundamental differences between MOR and the present situation. Today's response is characterized by a proliferation of a wide range of innovative solutions offered by a complex set of institutions and actors with great intellectual freedom and decentralized competition.

The third part of the report assesses some potential long-term impacts of the COVID-19 pandemic. We firstly discuss its impact on R\&D investment. We explain how innovation might be negatively affected by a prolonged economic downturn and highlight the crucial role of stimulus packages in confronting the recession. We also address the influence of the crisis on Information and Communication Technologies (ICT), arguing that it has been a formidable catalyst for ICT adoption. Next, we focus on clean technologies, another major societal challenge besides the pandemic. There are strong reasons for why cleantech investment may suffer. However, the crisis also offers significant opportunities to accelerate the green transition. Finally, we focus on open science, in particular on open access and open data. The current crisis could be a catalyst for the adoption of FAIR (Findable, Accessible, Interoperable, and Reusable) Data Practices.

The last part of the report offers some concluding thoughts. The STI policy response cannot be limited to the urgent need for 'technological fixes.' A second line of response involves the production of new knowledge to prevent outbreaks (ex-ante) or mitigate their effects (ex-post). Furthermore, the current crisis is a reminder that all branches of science matter. The pandemic has many facets, and a significant number of scientific disciplines can contribute to dealing with it. We conclude with a forward-looking note, arguing that the most substantial impact of the pandemic may lie outside of the public health realm or the science system. It offers a unique opportunity to adapt the set of rules that govern our society. 


\section{Résumé}

Ce document présente le point de vue d'économistes de l'innovation sur la pandémie actuelle. II s'adresse au grand public et se concentre sur les questions liées à l'écosystème de la science, de la technologie et de l'innovation (STI). II n'a pas pour but de présenter de nouveaux résultats de recherche. II fournit plutôt une lecture des développements actuels basée sur une approche économique et s'appuyant sur la recherche économique existante.

La première partie du rapport explique les causes profondes du sous-investissement général en recherche et développement (R\&D), avec un accent particulier sur les vaccins. Parmi ces causes figurent une demande insuffisante de vaccins en temps normal et la nature même de la R\&D. Les gouvernements peuvent intervenir pour atténuer ces problèmes, mais l'intervention gouvernementale s'accompagne d'une série de difficultés qui lui sont propres. Nous en discutons trois, à savoir le "free riding " (ou principe du passager clandestin), la définition des priorités de recherche et l'action basée sur des connaissances scientifiques.

La deuxième partie s'attarde sur les actions menées actuellement en termes de politique de STI. Premièrement, nous observons une importante réorientation des fonds vers la recherche sur le SRAS-CoV-2. Cette réorientation massive et soudaine ne risque-t-elle pas de mener à une utilisation inefficiente de ces ressources financières ? En utilisant le concept de "l'élasticité de la science ", nous soutenons que nous sommes loin d'une situation où des fonds supplémentaires représenteraient un gaspillage d'argent.

Une seconde observation marquante sur la situation actuelle concerne le niveau de coopération sans précédent entre les chercheurs. Cette coopération s'accompagne en parallèle d'une concurrence accrue pour réussir à avoir la primeur dans le développement de solutions thérapeutiques et de vaccins. Nous cherchons à donner un sens à cette antonymie apparente, en soulignant comment la combinaison de forces coopératives et compétitives peut stimuler la recherche scientifique.

Dans un troisième temps, nous examinons un outil particulièrement intéressant dans ce contexte : les brevets. Nous discutons le rôle de cet instrument de politique d'innovation et évaluons son potentiel effet néfaste sur la recherche d'une solution à la crise sanitaire actuelle. Nous mettons également en avant des moyens par lesquels les brevets peuvent être bénéfiques. Ils peuvent en effet accélérer la recherche (par exemple grâce aux groupements de brevets) ou assurer un meilleur accès aux innovations (par exemple grâce aux licences obligatoires).

Enfin, nous remarquons que l'ensemble de l'écosystème STI s'est rapidement recentré sur le SRAS-CoV-2. Ceci n'est pas sans rappeler les programmes de R\&D orientés sur mission (MOR) tels que le projet Manhattan dans les années 40 . Nous évaluons les similarités et nous soulignons les différences fondamentales entre les MOR et la situation actuelle. La réponse d'aujourd'hui se caractérise par la prolifération d'un large éventail de solutions innovantes proposées par un ensemble complexe d'institutions et d'acteurs jouissant d'une grande liberté intellectuelle et d'une concurrence décentralisée, ce qui n'était pas le cas pour les MOR.

La troisième partie du rapport évalue certains impacts potentiels à long terme de la pandémie de COVID-19. Nous discutons tout d'abord de son impact sur les investissements en R\&D. Nous expliquons comment l'innovation pourrait être affectée par un ralentissement économique prolongé et soulignons le rôle crucial des plans de relance pour faire face à la récession. Nous abordons également l'influence de la crise sur les technologies de l'information et de la communication (TIC), en faisant valoir qu'elle a été un formidable catalyseur pour l'adoption de ces technologies. Ensuite, nous nous concentrons sur les technologies propres, un autre défi sociétal majeur qui garde toute son importance malgré la pandémie. 
Il existe de fortes raisons de penser que les investissements dans les technologies propres pourraient souffrir de la crise économique et sanitaire. Cependant, cette dernière offre également d'importantes opportunités pour accélérer la transition vers une économie plus verte. Enfin, nous nous concentrons sur la science ouverte, en particulier sur le libre accès et les bases de données ouvertes. La crise actuelle pourrait être un catalyseur pour l'adoption de pratiques de données FAIR (Faciles à trouver, Accessibles, Interopérables et Réutilisables).

La dernière partie du rapport fait part de quelques réflexions en guise de conclusion. La réponse politique en matière de STI ne peut se limiter au besoin urgent de "solutions technologiques ». Une deuxième ligne de réponse implique la production de nouvelles connaissances pour prévenir les épidémies (ex-ante) ou atténuer leurs effets (ex-post). En outre, la crise actuelle nous rappelle que toutes les branches de la science sont importantes. La pandémie a de multiples facettes et un nombre important de disciplines scientifiques peuvent contribuer à y faire face. Nous concluons par une note prospective, argumentant que l'impact le plus important de la pandémie pourrait se situer en dehors du domaine de la santé publique ou du système scientifique. Cette crise nous offre une occasion unique d'adapter l'ensemble des règles qui régissent notre société. 
2. How did we get to this situation? $\quad 7$

$\begin{array}{ll}2.1 \text { Why don't we invest enough in vaccine research? } & 7\end{array}$

There is not enough demand for vaccines in normal times

$R \& D$ investment is subject to various failures 9

Yet another problem in the search for a solution to the underinvestment problem 9

What about the current crisis? 10

2.2 What other explanations beyond market failures? 11

Obvious progresses in public health, but some persistent failures 11

Setting research priorities $\quad 11$

Acting on scientific knowledge 12

3. Considerations on current STI policy reactions $\quad 12$

3.1 Is there an optimal investment level in SARS-CoV-2 research $\quad 12$

A remarkable shift of funds to cope with the new virus 12

How effective is it? 13

3.2. How to accelerate research: competition and cooperation 14

Which dynamic dominates in the COVID-19 crisis?

What are the long-term effects for scientific research?

3.3 Isn't the patent system blocking the search for a solution? 16

Patents are at the core of most innovative systems 16

Patents can block the search for a solution, but they can also accelerate it 16

3.4 Do we need mission-oriented R\&D policy to boost life science innovation? 18

4. Long-term impacts of the crisis $\quad 20$

4.1 The Impact of a COVID-19 recession on R\&D funding $\quad 20$

4.2 The long-term impact of the crisis on ICTs and AITs inventions and diffusion 22

Adoption of new ICTs based practices

Rate and direction of ICTs inventive activities 23

4.3 How could the crisis affect innovation in clean technologies?

The pandemic could derail plans to develop new clean technologies... 24

... but it also creates significant opportunities to accelerate the green transition 25

4.4 Changes in the organization of research: the open-science revolution 26

How did the current crisis affect the functioning of scientific research? 26

What long-term effects? 26

$\begin{array}{lr}\text { 5. Conclusion } & 27\end{array}$ 


\section{Introduction}

"Today the greatest risk of global catastrophe [is a virus]. If anything kills over ten million people in the next few decades, it's most likely to be a highly infectious virus rather than a war. Not missiles, but microbes. [...] We are not ready for the next epidemic."

Bill Gates, TED talk, 2015.

In a TED talk in March 2015, Bill Gates, a successful entrepreneur and philanthropist, warned the world that we were not ready to face "humanity's next biggest challenge": epidemic outbreaks (see also Gates 2015, 2018). The worst scenario, he said, would be "a virus where people feel well enough while they're infectious that they get on a plane or they go to a market," and that would spread through the air and hit urban areas. This hypothetical description is scarily close to the situation we are now facing. Bill Gates was not the only public figure warning us. Public organizations such as the WHO, the U.N. Office for Disaster Risk Reduction, the Red Cross and the U.S. National Institute of Allergy and Infectious disease have been communicating frequently about such risks in the past.

Meanwhile, scientists discovered that some strains of coronavirus had the potential to spread directly from bats to humans. In a 2013 paper published in Science, and discussed in the media, Xing-Yi Ge and colleagues found that "Chinese horseshoe bats are natural reservoirs of SARS-CoV, and that intermediate hosts may not be necessary for direct human infection by some bat SL-CoVs."

Piecing these two messages together suggests that we had a fairly good idea of what was coming. We had identified the potential source of the virus, even its location, and we knew we should take the risk of a pandemic seriously. Although some scholars have argued that the 2013 Ebola epidemic was a "Black Swan" event-an event so unlikely to happen and with such dramatic consequences that the world cannot possibly be prepared for it-the present pandemic is not a Black Swan event. We had enough knowledge to be better prepared to face the current pandemic. And as a matter of fact, many governments have been preparing to various degrees for pandemic-like crises. ${ }^{1}$ So how come society did not invest more in relevant research and innovation, such as a broad-spectrum antiviral drug or cost-effective, quick-to-produce ventilators?

The present document discusses this question, and others, from the viewpoint of innovation economists. What some may see as a failure of the Science, Technology, and Innovation (STI) ecosystem can be well explained by a few economic concepts. For instance, there are well-known reasons for why we do not invest enough in medical research-and solutions exist. Yet, despite obvious failures of the STI ecosystem, there is also a bright side to the current crisis. We clearly did not have the full picture, and we did not act as aggressively as we should have, but we have had several pockets of knowledge that are proving to be useful during the crisis. And we can rely on a strong base in science and technology to move forward fast. Indeed, many creative initiatives are emerging from public research organizations,

\footnotetext{
${ }^{1}$ See, for instance, the Swiss Influenza Pandemic Plan, last revised in 2018. Also, the U.S. government simulates a pandemic crisis as part of its transition from one president to the next.
} 
universities, private companies and individuals. The document highlights some of them and puts them in perspective.

Innovation is not only about the creation of inventions but also about their diffusion to society. In the present context, ensuring a wide diffusion takes particular significance as it translates directly into saved lives and economic growth. Diffusion resonates with the issue of access to drugs for developing economies. Although medical remedies are being largely produced by developed economies, they need to be made available for the whole world. ${ }^{2}$ This global policy perspective creates its own set of challenges, which this report touches upon at various places.

We would like to make three notes of caution. First, we have written this document for the general public. We have sought to strike the right balance between completeness and clarity but some issues are more complex than we have described. We encourage interested readers to delve into the many references that we provide. Second, this document is not a research paper. It is an attempt by innovation economists to use knowledge in our field in order to reflect on some issues related to the COVID-19 pandemic. We are convinced that we can shed light on the current situation from our own perspective with the view of enriching the public debate. Third, we are not health professionals or epidemiologists. We are utterly aware that we need more than effective STI policies to cope with the crisis efficiently, and to avoid other such crises in the future. Local and global health policies play a prime role, but all policy areas-including but not limited to defense, food, labor, and monetary-have a role to play.

The document is organized in three broad sections reflecting the past, the present and the future. We introduce some high-level concepts in Section 2 to explain how we have reached the situation we are currently in, from an STI standpoint. In Section 3, we discuss some current issues related to the COVID-19 crisis such as the surge in funding research on the virus and the new international collaboration patterns. Finally, in Section 4 we reflect on the potential long-term impacts of the crisis for the STI ecosystem. Although it is too early to draw all the lessons from what is happening, there is already a lot to take away.

\section{How did we get to this situation?}

\subsection{Why don't we invest enough in vaccine research?}

As the severity of the pandemic became clear, more than forty healthcare companies started developing COVID-19 vaccines. This surge in research investment will not negate the fact that the first vaccine should not be ready before at least 18 months. There is evidence that we could have been better prepared. An American researcher recently told the U.S. Congress that he and his team were working in 2016 on a vaccine against a strain of coronavirus based on some of their work on SARS, another respiratory disease. But, at the time, there was no interest in coronavirus research and he could not secure the necessary funding to pursue his research. Governments and companies are willing to massively fund vaccine research when there is an outbreak. However, when the outbreak wanes, so does funders' interest.

\footnotetext{
${ }^{2}$ On global access to medicines, see Moon (2007) who documents new policy tools and the underlying concepts.
} 
In contrast with many other 'products' of the pharmaceutical/biomedical industry, vaccines are subject to systematic underinvestment in research and development (R\&D) by private pharmaceutical companies. Two main explanations arise: the demand for vaccines, and the inherent characteristics of R\&D.

\section{There is not enough demand for vaccines in normal times}

Vaccines as an economic good are typically under-consumed. Their use by consumers is too low to induce firms to invest in vaccine research. A first explanation for this underconsumption relates to the fact that there is a 'positive externality' of being vaccinated. Individuals who take vaccines not only benefit themselves but also break the chain of disease transmission-thus benefiting the rest of the population. Therefore, not all individuals need to get vaccinated because they can free ride on those that are, a concept known as herd immunity. Second, consumers seem much more willing to pay for treatment than for prevention. This behavior encourages pharmaceutical companies to invest research money in drugs rather than in vaccines as shown by Kremer and Snyder (2015). Third, a great number of people in many countries do not believe that vaccination is a good means of protection, and many citizens place limited credence in official communications about the benefits of vaccination.

All these potential factors generate a smaller demand for vaccines than what could be expected for such an essential product for life. And because the demand is not large enough, potential vaccine developers lack incentives to invest in R\&D and in large-scale manufacturing facilities. As a matter of fact, few companies are active in this domain. Novartis' large vaccine division was sold to GSK in 2014 because it was incurring losses, leaving only five major players on the vaccine market, namely GSK, Merck, Sanofi, Pfizer and Novavax.

\section{Box 1. Definition of the term 'externality'}

Externalities occur in an economy when the production or consumption of a specific good or service impacts a third party that is not directly related to the production or consumption of that good or service. Externalities can either be positive or negative. For example, driving into a city center will cause external costs of more pollution and congestion to those living in the city. On the other hand, positive externalities occur when there are beneficial effects to people who are not involved in the action which generates such effects. In this paper, we use the concept of positive externalities to characterize two types of action: $i$ ) the action of being vaccinated (positive externalities include here herd immunity and reduced transmission of the disease) and; ii) the action of undertaking research and development (positive externalities come from the fact that inventors and innovators cannot keep others from also benefiting from their new knowledge). In both situations, people or firms do not consider the full social benefit of their actions when making their choices: i) the individual neglects the positive effect of his/her vaccination on other individuals and on society; ii) the firm will fail to undertake R\&D at a level of resource commitment that would be desirable if all R\&D benefits to society would be taken into account. In both cases, there is a market failure, which should require a policy intervention (see also Box 2). 
The economic concept of 'market failure' tells us that the production of new knowledge through R\&D (for instance a new vaccine) entails significant positive externalities that are difficult to capture by the innovator. In concrete terms, society benefits more from an innovation (social returns) than the payoff that the innovator will get (private returns). Economists have shown that this gap, sometimes very large, between social and private rates of return to inventions results in systematic underinvestment in R\&D. This situation leads to less inventions and discoveries than what is socially desirable. On top of that, the high risk involved in financing R\&D further reduces the incentives to perform R\&D. This argument is not specific to vaccines or drugs. It applies to R\&D projects from all fields.

Furthermore, vaccine (and drug) research is subject to a time consistency problem. It is characterized by high fixed costs for research but relatively low costs of manufacturing. Once vaccines are produced, governments are in a strong position to obtain vaccines at a price that will cover manufacturing costs, not R\&D costs. Since potential inventors anticipate this problem, they invest less in research than they would otherwise.

Yet another problem in the search for a solution to the underinvestment problem

All the reasons highlighted above explain why private developers lack incentives to pursue research on socially valuable projects in the vaccine industry. They provide mutually reinforcing reasons for why the world would be collectively better off if governments nurtured and supported vaccine R\&D.

And there is indeed a policy toolbox to address the systematic underinvestment in vaccine R\&D. One way to counteract this problem is to increase 'appropriability' in order to increase private returns, i.e., make it easier for innovators to profit from their innovations. This can be achieved via intellectual property (IP) protection. However, stronger IP leads to monopoly pricing, which exacerbates the issue of underconsumption. A patent enables the innovator to charge the price they want, and this price will be too high for some consumers.

Another way to address underinvestment involves various forms of government subsidies such as R\&D tax credits and subsidies. However, we operate in a globalized world. The world as a whole would be better off with public support for R\&D, but this is not necessarily true for countries taken individually. Indeed, national governments are interested in maximizing domestic welfare, not global welfare. Yet, vaccine R\&D is a global public good: once the vaccine has been invented, it becomes a commodity to which global access is open. In practice, this means that each country has an incentive to free ride on research financed by foreign governments or produced by foreign private sectors and IP systems (Kremer, 2000). This 'global perspective' weakens the incentives for national governments to invest in vaccine $R \& D$. 


\section{Box 2. Definition of the term 'market failure'}

Market failure is the economic situation typified by inefficient production or distribution of goods and services, which results in distortions in the 'free market.' A free market is a system in which the prices for goods and services are self-regulated by the open market and by consumers. Economists tend to identify three generic causes for market failure. The first is that externalities (whether positive or negative) drive a wedge between private and social returns from a particular private action (see Box 1). Other generic causes involve increasing returns and asymmetric information (not discussed in this paper). Governments and policymakers try to minimize market failure, seeking to strike a balance between protecting the interest of society and maintaining efficient markets.

\section{Box 3. Definition of the term 'public good'}

A public good is a technical term used by economists to characterize a commodity that an individual can consume without reducing its availability to others (non-rival in consumption) and of which no one is deprived (non-excludable). Because of these characteristics, the private provision of public goods confers an extreme form of an effect known as externalities (Box 1). The economic problem with public goods is therefore that in a free market the private actors will not invest enough in producing them. This is a market failure (Box 2). Classical examples of public goods include national defense, law enforcement, flood control systems and street lighting. As those examples reveal, public goods need almost always to be publicly financed. The vaccine itself is not (strictly speaking) a public good because the consumption of a vaccine reduces its availability. It is a rival good. But the herd immunity it provides is a public good and so is the knowledge that creates the possibility of inventing it. The invention and production of vaccines should then be supported by the government to fix potential market failures in this domain.

\section{What about the current crisis?}

Faced with the dramatic situation, various actors have joined forces to come up with new mechanisms to alleviate the problems highlighted. In particular, two new mechanisms encourage companies to do more research on vaccines, increase production capacity and price them reasonably (i.e., close to production costs). These mechanisms are public private partnerships for vaccine development on the one hand and advanced market commitment such as research prizes on the other hand.

Today, vaccine developers are working with unprecedented speed since the first genome sequence of the SARS-CoV-2 was released in January. The rapid acceleration of public and private funding that we are witnessing provides further evidence that market failures matter a lot. Opportunely, market failures for vaccine consumption have dissipated for SARS-CoV-2. Millions, if not billions, of people demand access to it, and a significant fraction of consumers are willing to pay a higher price than the manufacturing cost. Furthermore, most market failures related to R\&D have disappeared as well. Competition across 
countries to be the first to have access to new vaccines also mitigates the free rider problem and strengthens R\&D incentives.

\subsection{What other explanations beyond market failures?}

\section{Obvious progresses in public health, but some persistent failures}

The preceding section explains why a pure unfettered market might not deliver an efficient level of health services to society. Those market failures suggest that it is not enough to patch up the market to ensure a sufficient level of provision of medical R\&D. One may argue that the best way forward is to rely on the market but to supplement it with strong government interventions. The preceding section also hints to the fact that government intervention comes with its own set of problems, as the 'global public good' aspect of vaccines exemplifies.

Looking beyond the current pandemic, and considering health-related research in general, government commitment is both strong and clear. Indeed, governments from most democracies have invested heavily in health research and services. Since World War II (WWII), it has been standard practice for most societies to contribute a substantial amount of public monies to medical research and disease prevention via research grants, public health programs and subsidized medical care. Government budget outlays for health-related R\&D reached $\$ 11$ billion in Europe in 2014, compared to $\$ 26$ billion for business enterprises expenditure. Furthermore, 73 percent of general health spending in OECD countries comes from public sources (the figure reaches 66 percent for Switzerland). In many cases, the government operates facilities in addition to financing them, such as INSERM in France and the National Institute of Health $(\mathrm{NIH})$ campus in the United States.

Overall, government intervention largely works. It is indisputable that health-related quality of life has improved dramatically in the last century. However, quite a few public health problems still represent major societal challenges, including not only the need to have a ready response to contagious pandemics but also antibiotic resistance, tobacco consumption, sugar consumption, mental health, and drug addiction. We have the capabilities, and often the ready knowledge, to solve or manage these ills, but we are not always succeeding in doing it. Several salient issues arise when it comes to STI policy, and we will highlight two of them: setting research priorities and acting on scientific knowledge.

\section{Setting research priorities}

Regarding the setting of research priorities, policy making is a matter of trade-offs. Governments have many high-level priorities and limited funding leading to complicated decisions. If we think back to the pre-COVID-19 times, pandemics, in the eye of the public, were not on the top of the list of the risks we had to fight. Politicians and electors alike were more focused on climate change, other health issues (like antibiotic resistance for instance) and several crucial economic objectives such as fighting unemployment and ensuring sustainable retirement plans for the population. In this context, putting too much public money into preventing a disease would have been met with skepticism, to say the least ${ }^{3}$.

\footnotetext{
${ }^{3}$ See Sampat (2012) for an excellent study on priority setting at the NIH.
} 
Regarding acting on scientific knowledge, scientists are just one voice among many others including lobby groups and public opinion. Many welfare-increasing reforms were introduced belatedly only after decades of campaigning by experts and in the face of opposition from vested financial interests (smoking, sugar consumption, drink driving, lead in petrol, ozone layer gases), see, e.g., Fredriksson et al. (2007) and Van den Hove et al. (2002). And indeed research is a complex beast. It can be funded by interest groups and used for political lobbying. Recently, fossil fuel companies and their funders such as ExxonMobil and Koch Foundation have been funding research that disputes the consensus on climate change in defense of their own political and financial interests.

Beyond lobby groups, another issue is the misalignment of short-term policies and long-term priority setting. One can argue that there is little preparedness and social consideration for issues such as pandemics and climate change, because the estimated political payoffs from investing in climate- and pandemic-related projects are small. Short-term policies and those that align with vested commercial interests have the largest political payoff. Trump's recent budget cuts exemplify the case. He gave the green light to research investments in Artificial Intelligence, quantum computing, 5G, etc. despite an overall cut in research spending, because "[these fields] are vital to the nation's global competitiveness and the health, prosperity, and security of the American people".

Finally, yet another issue relates to the biases in the decision process that affects politicians and individuals alike. Part of our past decisions were guided by cognitive biases such as the 'probability neglect' and the short sightedness that explains our limited action against seemingly distant threats to humanity. These biases also lead a non-negligible fraction of the population not to believe what experts and scientists are telling them unless they can see tangible evidence that affects them directly. We find cancer patients still smoking, people suffering from obesity not limiting their sugar consumption and drug addicts still being treated as criminals. This non-belief is not specific to health issues: it affects other long-term, latent issues such as climate change.

\section{Considerations on current STI policy reactions}

\subsection{Is there an optimal investment level in SARS-CoV-2 research}

A remarkable shift of funds to cope with the new virus

The case for investing in research to prevent pandemic outbreaks may have been strong. However, now that a pandemic is upon us, and given the many demands on the public purse, is it wise to invest large amounts in COVID-19 research? Indeed, public funders such as the European Commission and the SNSF are multiplying initiatives to fund SARS-CoV-2 research. The NIH alone has received \$1.8 billion.

The SARS-CoV-2 has emerged as an unmet medical need of massive proportions. The human costs in terms of lives lost but also of anxiety and isolation for many are large but difficult to quantify. However, some figures on the economic costs in the United States alone point to the magnitude of the problem. In a couple of weeks, U.S. equity markets have lost 11.5 trillion dollars in market capitalization. The latest 
relief package for the U.S. economy is worth 2 trillion dollars. Either of these figures are considerably larger than worldwide yearly sales for all pharmaceutical products combined, which stand at around \$1.3 trillion. The world is desperate for new pharmaceutical products that could prevent, treat, or at least help detect SARS-CoV-2.

\section{How effective is it?}

How many scientists, medical researchers and pharmaceutical companies should switch their efforts towards SARS-CoV-2 prevention, treatment or mitigation? In the short run, only a subset of researchers have the right human capital to advance the knowledge frontier in any specific area. While more research on the 'elasticity of science' with respect to targeted funding is needed, work by Kyle Myers (forthcoming) suggests that switching costs of science are large. ${ }^{4}$ Human capital is not the only barrier: good research ideas may also be scarce. In a world of scarce ideas-a theme much emphasized in the work of the late Suzanne Scotchmer (Scotchmer, 2004)-increasing funding invariably leads to diminishing returns. That is, the most promising ideas are explored first and the productivity of additional researchers is lower since they must work on less promising ideas (see also Bloom et al., 2020). Finally, the unmet medical needs of yesterday have not gone away and pharmaceutical innovation for all sorts of other diseases is still needed, calling for a cautious reallocation of research efforts.

The previous considerations suggest that reallocating vast amounts of funding to SARS-CoV-2-related research could be wasteful. However, they should also be taken with caution. The scarcity of ideas may be a factor, but the current virus has not been the focus of research for a long time. Therefore, we may be far from diminishing returns kicking in. As far as the human capital constraint is concerned, this may be mitigated by the fact that a wide range of innovations could be useful to fight COVID-19, from vaccines, drugs and medical equipment to innovation in testing. Immunologists may work on vaccine development while microbiologists focus on testing and engineers put their efforts on new protective equipment and ventilators.

While the optimal level of SARS-CoV-2 public research support is unclear, we believe that in the long term there is a strong case for considerably more support than is presently the case. The discrepancy between the needs and the current level of support is stupendous. The NIH COVID-19 budget may sound large but it represents only 4 percent of the total annual NIH budget and one tenth of a percent of the U.S. relief package. As the pandemic paralyzes the economy of most advanced countries, outside China SARS-CoV-2 clinical trials are less than 1 percent of the total number of clinical trials currently underway. ${ }^{5}$ It is likely that we will not see investment in research to fight COVID resulting in major progress in the immediate future. However, given the stakes involved, even minor innovations could be useful and the upside of a breakthrough is massive. It is also possible that innovation in the medium run could be incredibly valuable. In the longer run, policy should aim not just at increasing spending but at increasing the total quantity of inputs that go into the research, and in particular human capital at the right level of skills and knowledge.

\footnotetext{
${ }^{4}$ The term 'elasticity of science' designates the extent to which scientific production reacts to a change in funding.

${ }^{5}$ The 1-percent figure is based on authors' calculations from clinicaltrials.gov data accessed 21 March 2020.
} 


\section{Box 4. Definition of the term 'human capital'}

Human capital is the stock of knowledge, skills, competencies and other attributes embodied in individuals or groups of individuals acquired during their life and used to produce goods, services or ideas. Human capital is one of the key drivers of innovation and sustained competitive advantage. For this reason, governments and policymakers put in place policies to sustain and increase the supply of human capital. These policies include, but are not limited to, a strong education system and on-the-job training opportunities.

\subsection{How to accelerate research: competition and cooperation}

The dramatic consequences of the novel coronavirus outbreak need to be urgently addressed with medical remedies. While new diagnostic technologies have rapidly emerged and have already been approved by medical authorities, therapeutic and immunization solutions will need more time. Provided the discovery of a promising candidate, drug and vaccine developments involve relatively long clinical trial phases aimed at assessing their effectiveness and the absence of side effects. Some experts recently estimated that a vaccine might take at least 18 months to be brought to market.

\section{Which dynamic dominates in the COVID-19 crisis?}

The urgency to address the virus outbreak with medical remedies and the regulatory length of the process to obtain them lead us to ask how research could be accelerated to obtain them as soon as possible. As economists, we are often concerned with the efficient allocation of resources, how market-mediated interactions influence it, and the best policies to achieve socially desirable outcomes while avoiding inefficiencies. The quest for an antiviral drug or vaccine could display more or less competitive and cooperative behavior among academics and within the pharmaceutical sector. How do cooperation and competition interact and influence COVID-19 research speed? Which policies might accelerate research by providing the right incentive schemes for the actors involved to contribute?

At the time of writing, both cooperative and competitive forces are shaping research on COVID-19. The severity of the pandemic has increased academic scientists' willingness to share data and results (see Section 4.4). Furthermore, joint public-private initiatives (involving major pharmaceutical corporations and startups, governmental agencies, universities and philanthropic organizations) have emerged over the past weeks. Yet, alongside these moral motivations, which have led to more sharing, the possibility of winning a prestigious and lucrative discovery race has also increased competition. This competitive push is observed also at the international level, as the search for COVID-19 anti-viral drugs and vaccines enters geopolitical considerations.

Cooperation and competition become pure antonyms only in their extreme forms (all actors competing in silos versus all actors cooperating in a unique collaboration). In practice, we see a range of cooperative and competitive behaviors. Cooperation goes from simple openness in sharing relevant data to partnerships involving common resources, infrastructure, and personnel. Likewise, competition can take different levels of intensity. These behaviors occur concomitantly, one taking some elements of the 
other. For example, simply being more open to share information and data about the virus doesn't eliminate a competitive race to be the first to find a valid candidate treatment or vaccine. Also, while a cooperative spirit might emerge in a certain country, fierce competition can still prevail at the international level.

Cooperation has the potential to accelerate research in a number of ways. It enables the construction of a larger knowledge base than in isolation ${ }^{6}$ and ensures faster identification of unfruitful research paths that can be abandoned quickly. When direct collaboration is involved, it can prevent duplication, reduce redundancy, and create synergies based upon specialization and labor division. Nevertheless, as cooperation increases so do coordination costs, creating potential bottlenecks with detrimental rather than positive effects on research speed. ${ }^{7}$ Competition induces a race that accelerates research by both academic and industrial actors-although it can also generate obstacles since disclosing crucial data and information can improve competitors' positions and reduce one's chances to succeed.

What are the long-term effects for scientific research?

Measures to balance competition and cooperation trade-offs and accelerate research must necessarily consider academic scientists' and pharmaceutical companies' distinct incentives and operational settings. Academic research is a very competitive environment where establishing priority for a discovery and gaining recognition for it are key incentives (Merton, 1957; Stephan, 2012). Yet, it also exhibits cooperative traits, especially after key results are published and priority is certified. The pharmaceutical sector is certainly not less competitive and research investment decisions depend chiefly on expected future financial returns (see Section 2.1) with a relatively closed environment where compound libraries, research data and findings constitute crucial strategic assets and are not usually shared.

Therefore, frictions related to the characteristics and objectives of the actors involved might obstruct efforts stimulating either competition or cooperation or even annihilate their effects. In academia, research could be accelerated by attempts to get COVID-19 research published faster and boost dissemination and consequently global knowledge availability. Competition could positively affect research speed through increases in funding opportunities and higher-than-average research budgets for COVID-19 research. The pharmaceutical industry's relatively closed and hyper-competitive environment makes programs directed at boosting cooperation within it less practicable. Antitrust tensions between potential strategic usages of the virus outbreak to gain market power and the need to 'legally' cooperate further complicate their design. In this sense, rather than aiming at more firm-to-firm collaborations, the government could try to increase industry's contribution ${ }^{8}$ to publicly available COVID-19 knowledge or setting up a prize-with no patent-to be shared by all parties with verifiable inputs (see also Section 3.5).

\footnotetext{
${ }^{6}$ One example is the diffusion of information on the virus genetic sequence by Chinese researchers who were firstly confronted with its challenges in early January, enabling scientists around the world to quickly advance their COVID-19 projects.

${ }^{7}$ Coordination costs can increase with the breadth of collaborative efforts, cultural and language differences, and work approaches and routines differences.

${ }^{8}$ See for example the 'Melloddy' project.
} 
The case for an increased public availability of industrial data is particularly pressing for clinical trials, a peculiar segment of the product development process with a strong public good dimension. Leaving private firms with the burden of clinical testing makes clinical trials results artificially scarce and excludable (because they have paid for the trials and own the data). Lewis et al. (2007) make a strong case for shifting clinical trials from the private to the public sector. He argues that this will lead to a lowering of drug companies' costs, which will subsequently benefit consumers and induce long-run efficiencies in drug discovery and development. In this sense, measures to increase the role of the public sector in clinical trials could play a crucial role in accelerating COVID-19 research.

\subsection{Isn't the patent system blocking the search for a solution?}

The worry that patents, and other forms of IP rights, may be a barrier in the fight against COVID-19 is a legitimate concern. After all, a patent is a temporary monopoly right granted to an inventor that allows her to exclude others from using, making and selling the protected invention (see also Box 5). Excluding others from using bright ideas may seem counterproductive in present times.

\section{Patents are at the core of most innovative systems}

Traditionally, patents are seen as a catalyst for research and innovation. As explained in Box 2, knowledge is a 'public good,' meaning that it is difficult to exclude others from using it and that the use by one person does not reduce its availability to other potential users. A given piece of knowledge usually generates more benefits for society as a whole than what a private actor can possibly extract from its creation and commercialization. Therefore, economists consider that the incentives that an innovator has in producing new knowledge are suboptimal from society's viewpoint-and the patent system provides one way of increasing these incentives.

The pharmaceutical industry offers a compelling case for patent protection. Creating a new drug is risky, lengthy, and (very) expensive. Yet, once the active compound of a drug is identified and tested, copying it is usually easy and producing the drug is very cheap. Therefore, without patent protection, few, if any, private companies would be in the drug development business. Put simply, the monopoly power that patent protection confers acts as a carrot that pushes firms to invest in research and development. However, patent protection is not a perfect incentive mechanism. Scholars have noted, among others, that recovery of research costs by patent monopoly reduces access to drugs and that market demand, rather than health needs, determines research priorities (e.g., Barton and Emanuel, 2005).

It is challenging to determine whether other incentive mechanisms would be superior to patent protection to foster medical research. Answering this question is beyond the scope of the present document. It is a fact that the technology space is patent protected, and some actors are rushing to file patent applications. As a result, the various parties involved in the search for solutions may inadvertently or willfully infringe on granted patents.

Patents can block the search for a solution, but they can also accelerate it

The issue is real. BioFire Diagnostics, a medical device firm based in the United States, was recently sued by Labrador Diagnostics for patent infringement. ${ }^{9}$ BioFire launched three Covid-19 tests built off of the company's technology but that allegedly infringe on two of Labrador Diagnostics's patents. The plaintiff

\footnotetext{
${ }^{9}$ See also

https://www.theverge.com/2020/3/18/21185006/softbank-theranos-coronavirus-covid-lawsuit-patent-testing
} 
demanded that the court forbid the firm from making those Covid-19 tests. In another widely discussed case, U.S. pharmaceutical company Gilead took a number of steps suggesting they were ready to enforce their patent rights related to COVID-19 candidate drug Remdesivir. An open letter signed by more than 140 NGOs asks Gilead to take actions to ensure rapid availability, affordability, and accessibility of Remdesivir. The letter concludes saying that an "exclusivity and monopoly-based approach will fail the world in combating the COVID-19 pandemic."

At the other end of the spectrum, a couple of patent holders have already given up patent rights or granted free licenses to relevant patents. For instance, U.S. drug maker AbbVie is reportedly waiving its right to exclusivity over patent-protected Kaletra, a combination of the antivirals lopinavir and ritonavir that is being used-and whose efficacy is still being tested-to treat patients with coronavirus. This would allow the production of generic versions of the drug to be made by others without the risk of being sued for patent infringement. In a lower-tech setting, French sporting goods company Decathlon is providing its patent protecting its snorkeling mask Easybreath for free. This mask has been first transformed by hospitals in the north of Italy as a protective mask and has later been adapted to be used in ventilators.

Individual initiatives of voluntarily sharing patents are a welcome development. To accelerate the trend, proposals such as the Open COVID pledge are emerging. Signatories to the pledge commit to making patents that could be used in ending the COVID-19 pandemic available for free and without encumbrances. ${ }^{10}$ Patent pledges are not new but their popularity seems to have increased in the recent past. Notable examples include the Open Patent Non-Assertion Pledge, in which Google pledges the free use of certain of its patents in connection with Free or Open Source Software, and the patent pledge by electric car company Tesla. Traditionally, patent pledges come with benefits for the patent holder, such as a greater adoption of its technology and a freer environment. ${ }^{11}$ In the present context, patent pledges have the potential to accelerate innovation by pointing to relevant patents, by offering some legal certainty to follow-on innovators (reinforced by the public commitment of the patent holder to the patent pledge), and by reducing transaction costs (that is, the cost of negotiating and drafting a contract with every potential user of the technology).

Finally, the creation of a 'patent pool' would be a clear catalyst in the search for a solution, and later vaccine adoption. Patent pools are a collection of patents from different patent holders available in bulk, for free or for a fee. Governments have already called on the WHO for the creation of a SARS-CoV-2 patent pool-the UN has already done so in the past, having established one for HIV drugs, tuberculosis and hepatitis C (Burrone et al. 2019). Because patents in a pool are available in one place, under clear terms, and generally at a reasonable price, they reduce litigation risks and lead to lower licensing fees and transaction costs among participating firms. Furthermore, medicine patent pools encourage the diffusion of drugs to developing countries with lower prices (see, e.g., Wang 2019 on HIV cocktails).

If voluntary contributions fail, governments can step in and force patent holders to share their inventions. Indeed, patent laws of many countries include 'compulsory licensing' provisions that allow

\footnotetext{
${ }^{10}$ For more information, see

https://www.iam-media.com/copyright/new-patent-pledge-underlines-delicate-balancing-act-companies-must-stri ke-in-covid-19

${ }^{11}$ See, for instance, regarding the Tesla pledge:

https://www.finnegan.com/en/insights/articles/maximizing-a-patent-s-value-by-pledging-not-to-assert-it.html https://www.lexology.com/library/detail.aspx?g=ca6c332f-2cc5-401b-b80d-36473d0754c7
} 
governments to forcibly license a patented invention when there is a threat to public safety. Some countries have actually reinforced their legislative base to speed up compulsory licensing and generic drug production. ${ }^{12}$ NGOs such as Médecins Sans Frontières (MSF) actively call for governments "to prepare to suspend or override patents for COVID-19 medical tools by issuing compulsory licenses."

Clearly, the first-best solution would be for private actors to act responsibly by providing a broad and affordable access to tests, drugs, and vaccines. Government intervention is certainly an option to consider-if only because the threat of compulsory licensing encourages patent holders to act responsibly. Actual implementation of compulsory licensing is challenging but a real option on the table.

\subsection{Do we need mission-oriented R\&D policy to boost life science innovation?}

The current crisis-characterized by the innovation imperative of finding a vaccine very quickly and at any cost-seems to represent a strong case for organizing research and allocating resources under a logic of 'mission-oriented R\&D policy' (MOR). Archetypal examples of MOR have been the Manhattan Project and the development of penicillin during WWII as well as President Kennedy's Apollo moonshot. Such policies are characterized by a high level of centralization and intentionality (there is a specific and well defined technology target) and a certain simplicity between the set of agents that are involved: the State is both the funder and the customer and some public agencies are performing the R\&D operations. MOR has been mostly deployed in defense and space sectors and has delivered significant results in terms of goal achievement (landing a man on the moon, inventing the atomic bomb) within a rather short time period. MOR seems thus an appropriate approach in any crisis time, when a particular 'technological fix' is needed urgently (Sarewitz and Nelson, 2008). It also comes with a great drawback: the lack of organizational diversity and freedom to experiment, which is a key engine for innovation (Rosenberg, 1992).

This drawback explains why the life sciences ecosystem has never worked under such a MOR principle. Quite the opposite: "In contrast to a Manhattan project approach in which a single burst of focused investment yields a single technological fix, the life sciences system of innovation has been characterized by steady and cumulative progress over time and the development of complementary platform technologies. Indeed a single R\&D surge seems to have never paid-off in the pharma industry and has been actually counterproductive" (Cockburn et al., 2011). The success of the life science innovation system has been driven on the one hand by intellectual freedom, scientific openness and opportunities for experimentation and diversity at the level of individuals and institutions, and on the other hand by an intense and pervasive competition throughout the value chain in life science. Successful life science innovation systems seem to involve freedom to experiment and competition rather than a command-and-control approach.

What we are observing today as a reaction to the pandemic crisis is not really the creation of a new Manhattan Project but rather a proliferation of a wide range of responses by a complex set of institutions and actors. This organization maintains and promotes intellectual freedom, scientific openness and decentralized competition at all stages of the research and product development process-although all these behaviors and strategies are currently molded by the intensity of demand for a certain type of good. As a policy guidance for future crises, how the system is responding now is

\footnotetext{
${ }^{12}$ See also the case of Ecuador: https://www.keionline.org/32429
} 
probably a better solution than what could be organized under a MOR principle, even when a particular public health priority is emerging.

\section{Box 5. Inside the toolkit to promote innovation: Patent, prize and R\&D subsidies}

Patent, prize and R\&D subsidies: Three leverages for innovation policy. In various parts of Sections 2 and 3, we have mentioned several innovation policy tools that can be used and deployed to stimulate R\&D and enhance innovation capacities. This section gives a brief overview of these tools, highlighting their pros and cons. We focus here on the three main policy levers that directly influence incentives to innovate: patent, prize, and R\&D subsidies. A patent is an exclusive monopoly right given to the inventor of a novel solution, be it a product, a process or a design (see also Section 3.3). A prize is a reward for achieving a predefined innovation goal. An R\&D subsidy is a publicly provided financing for performing research in a given field. There are other important but indirect instruments to support innovation such as human capital supply or product market competition. ${ }^{13}$ We only focus on the direct instruments for brevity.

Table 1 assesses the instruments along the following criteria:

- Incentives. Does the instrument provide strong incentives to R\&D and other innovation-related activities?

- Diffusion/access. Does the instrument favor diffusion and access to society once the invention has been produced?

- Direction. Does the instrument influence the direction of innovation (allow to reach a specific target instead of innovation in general)?

- Competition. Does the instrument stimulate or freeze competition?

- Monitoring. Is the instrument easily monitored, and final results easily evaluated?

- Funding decisions. Does the instrument require significant informational inputs to support funding decisions?

${ }^{13}$ See, e.g., Roberts (1999) and Eicher(1996). 
Table 1. Overview of STI policy tools

\begin{tabular}{|c|c|c|c|}
\hline & Patent & Prize & Subsidies \\
\hline Incentives & $\begin{array}{l}+ \\
\text { Ex-post reward, hence } \\
\text { some risks: patenting } \\
\text { around, litigation }\end{array}$ & $\begin{array}{l}+ \\
\text { Ex-post reward. Hard to } \\
\text { commit for a prize only } \\
\text { obtained many years later }\end{array}$ & $\begin{array}{l}++ \\
\text { The subsidy is } \\
\text { provided ex-ante }\end{array}$ \\
\hline Diffusion & $\begin{array}{l}-+ \\
\text { Risk of monopoly } \\
\text { pricing but useful to } \\
\text { support the market for } \\
\text { technologies }\end{array}$ & $\begin{array}{l}++ \\
\text { In exchange of a prize, the } \\
\text { invention is put into the } \\
\text { public domain }\end{array}$ & $\begin{array}{l}\text { Neutral (when only } \\
\text { targeted at the } \\
\text { production of R\&D) }\end{array}$ \\
\hline Direction & $\begin{array}{l}\text { Patents do not influence } \\
\text { the direction of } R \& D\end{array}$ & $\begin{array}{l}++ \\
\text { The best system to } \\
\text { influence the direction of } \\
\text { R\&D }\end{array}$ & $\begin{array}{l}+ \\
\text { Can influence } \\
\text { direction but harder } \\
\text { to monitor }\end{array}$ \\
\hline Competition & $\begin{array}{l}++ \\
\text { Patent race }\end{array}$ & $\begin{array}{l}++ \\
\text { Prize race }\end{array}$ & Neutral \\
\hline Monitoring & $\begin{array}{l}++ \\
\text { Ex post reward. No big } \\
\text { issue }\end{array}$ & $\begin{array}{l}+- \\
\text { Ex-post reward. Issue of } \\
\text { evaluating the result }\end{array}$ & $\begin{array}{l}\text { Hard to monitor: } \\
\text { Information } \\
\text { asymmetry, moral } \\
\text { hazard }\end{array}$ \\
\hline Funding decision & No funding decision & $\begin{array}{l}++ \\
\text { Pay for output }\end{array}$ & $\begin{array}{l}\text {-- } \\
\text { ex-anplex issues of } \\
\text { exte assessment }\end{array}$ \\
\hline Possible corrections & $\begin{array}{l}\text { Patent pool, compulsory } \\
\text { licensing }\end{array}$ & & $\begin{array}{l}\text { Multiple funding } \\
\text { decisions }\end{array}$ \\
\hline
\end{tabular}

\section{Long-term impacts of the crisis}

\subsection{The Impact of a COVID-19 recession on R\&D funding}

Alongside its direct harmful effects on health, the COVID-19 outbreak is showing its first negative economic repercussions, bound to be very large in the medium and long term (see also Baldwin and Weder Di Mauro, 2020). The lockdown measures implemented in many countries around the world to 
stop the virus spreading have halted a significant portion of global economic activities, starting a recession period whose severity and length is difficult to predict.

A major economic downturn will affect the availability of financial resources and shift their allocation, challenging research and innovation dynamics. Regarding public spending, governments will need to address tensions between fiscal interventions and their budget constraints. As for private spendings, many firms will focus on survival, reassessing their expenses and investment plans to ensure solvability. In this scenario, the (potential) long-term returns of R\&D contrast with the public and private spheres' urgent liquidity needs to address short-term operational issues. Research is likely to be one of the first budget items to be cut (e.g., Cincera et al., 2011).

These considerations are at the basis of a 'pro-cyclical' view of R\&D, a term used by economists to express how private R\&D follows business cycle's fluctuations, with more investments during booms and less during recessions. ${ }^{14}$ R\&D pro-cyclicality during a COVID-19 recession could be accentuated by many factors. Let's not be mistaken: the 'fundamentals' of the innovation economy are strong. There is no decrease in technological opportunities and in demand, with in fact increased demand for technology in domains such as pharmaceuticals, medical technologies, ICT and machine learning applications (see Section 4.2). But several factors predict challenging times ahead. Firstly, sustaining the innovation potential of small, undiversified, cash-hungry and externally financed firms will be difficult. A contraction of Venture Capital and IPO capital markets will exert severe pressure on innovation, as does any rise in the equity risk premium. Secondly, the drying out of industry funding for R\&D will also reverberate to external performers of $R \& D$ such as universities. Indeed, evidence suggests that industry-funded investments in externally-performed R\&D declines in times of recession (Azagra-Caro et al., 2019). Finally, the role of public funders in R\&D financing has been shrinking during the past 25 years, witnessing rather decisive shifts towards a greater portion of R\&D money coming from the private sector. ${ }^{15}$ The deterioration of firms' financial health jeopardizes R\&D investments to an extent that public funders won't be able to compensate.

Despite a decrease in the role of public funders in R\&D financing, 'counter-cyclical' R\&D subsidies should be part of measures to ensure economic recovery (Artisei et al., 2016). Rather than a 'budget conundrum,' R\&D investments become an opportunity to address the looming COVID-19 recession (Brautzch et al. 2015, Hud and Hussinger, 2015). This will require strong commitment from governments, where stimulus packages will need to include a comprehensive innovation strategy involving the public sphere, businesses and society to stimulate demand and supply for research, development and its applications. It will also need to recognize technological sectors' heterogeneity, as certain domains (e.g., pharmaceutical, biotechnology, medical equipment) will already be at the top of science and innovation agendas while others could lag behind. In this sense, new policy frameworks should be explicitly aimed at the creation and use (commercial and non-commercial) of knowledge in all areas where the centrality

\footnotetext{
${ }^{14}$ Although there are theoretical arguments that recessions should ideally promote R\&D activities because the opportunity costs of achieving productivity growth is lower in recessions, empirical evidence shows that R\&D is pro-cyclical (Barlevy, 2007; Jensen and Webster, 2011).

${ }^{15}$ For an overview of current private \& public sector R\&D spending across countries see $\underline{\text { UNESCO }}$ and $\underline{\text { OECD }}$ data.
} 
of R\&D and innovation is emerging as a solution to structural problems, such asc healthcare, but also energy and climate change research.

As the current and future economic environment will be characterized by continued underutilization of tangible capital and a potential threat of erosion in human, knowledge and other intangible capital, the most urgent matter is to devise national and/or regional investment plans for innovation. It is here that the interests of government and business coincide and complement each other. It is also here where the strengthening supply (better inputs) and demand (more sophisticated customers) for innovation meet. Such an investment plan for innovation to address societal grand challenges is a concrete step that can be taken as a follow up to the short term fiscal stimulus plans emphasizing the role for innovation as the main driver for long-term growth.

\subsection{The long-term impact of the crisis on ICTs and AITs inventions and diffusion}

We do not have a crystal ball and we cannot, therefore, predict the future developments of inventions and innovations in information and communication technologies (ICTs). However, it is obvious that the impact of the crisis on these developments will be significant. To explore this issue, we can rely on a simple framework that differentiates invention and adoption on the one hand and the rate and direction of inventive activities in ICTs on the other hand.

\section{Adoption of new ICTs based practices}

Adoption (or diffusion) of inventions is as important as the inventions themselves for realizing the full potential of a technology in terms of productivity increase and societal transformations. If an invention is not diffused (i.e., adopted by consumers, firms, organizations), its impact will be close to nil.

The current crisis is likely to generate a considerable step change in the adoption of ICTs, with particular emphasis on certain kinds of applications. For more than one decade now, the ICTs infrastructure has provided a set of collaborative tools to create efficient conditions for long-distance communication and collaboration in many professions and social activities and these tools are continuously improving.

Scientists have certainly been early adopters of these tools, together with some other groups of 'knowledge workers' (Atkins, 2007). Yet, adoption has remained limited in light of the vast potential that these tools offer not only for science but also for, say, product development, design, architecture, management, as well as education or healthcare provision. Scientists continued to fly to physically attend big conferences in their disciplines; they continued to travel to participate in evaluation boards or to be part of laboratory visits as members of an audit committee. The same was true for most other professions and social activities.

What prevented a wider and quicker adoption of new online collaborative practices was not the lack of a suitable technology, but rather the inertia of certain beliefs (Coch and French, 1948), mind-sets and practices. It was a widespread belief that many types of human interactions are better performed when people are in the same room rather than working at a distance (e.g., Patti et al., 1997). Building trust, communicating nuanced information, generating rapid feedback, using multiple channels (faces, bodies, 
gestures) to communicate emotions or sharing local contexts were all key characteristics of collocated synchronous interactions that were considered as poorly supported by an ICT infrastructure (Olson and Olson, 2003). Even the climate change challenge, which calls for radically revisiting our current mobility patterns, did not really influence the preference for radical collocation-not even among scientists who all are taking climate change very seriously.

An exogenous shock, such as the current crisis, was needed to foster adoption. It obliges everybody to stay home, forces all to engage in long-distance collaborations and interactions and, therefore, to reconsider their beliefs and mindsets. Everybody now realizes that the key characteristics of collocated synchronous interactions are not so poorly supported by technologies. And the current massive experiments around adopting new practices will change dramatically the future of ICTs as technologies to support long-distance, complex interactions. The case of EPFL and many other campuses is striking. The shift to online teaching and remote research collaboration has been remarkably managed within a couple of days. This means that all technologies were available and ready to be deployed. What was missing before the crisis was precisely a crisis to force the institution-administration, professors, students - to engage itself into such a regime shift.

The current crisis has produced a large and unexpected push towards the adoption of new practices, and we will probably not return to the previous situation. We described the case of long-distance interactions and collaborations. But the same logic applies to many habits such as, for instance, contactless payments. A virtuous dynamic of innovation and diffusion is likely to happen. The greater diffusion of these new practices will increase the size of the market for such applications and improve the economic return on inventive activities in this specific domain. These dynamic feedback loops can trigger the development of a long-term effect, consisting of large-scale investments in research and innovation in this domain.

\section{Rate and direction of ICTs inventive activities}

In his insightful paper on machine-learning-driven inventions and applications, Bresnahan (2019) shows that artificial intelligence technologies (AITS) represent a highly valuable group of technologies that determines a substantial increase in the rate of innovation in ICTs. They do not, however, represent a major change in the direction of innovation. He shows that the most economically significant AIT applications follow a ' $21^{\text {st }}$ century trend.' AITs find their most successful deployments in consumer-oriented applications (including retail, entertainment, mass market product and service businesses) and devices (such as smartphones and tablets) as well as in mass-market marketing and sales applications. Outside of these very profitable domains, applications of AITs have had negligible impact in terms of revenues, profits and diffusion-although they have generated excitement and spinned off useful applications. In other words: high inventive rate, but same direction.

However, the current crisis may change the direction of AlTs innovations. The failures in terms of logistics that happened in most countries may boost applications of AITs. These failures include production scheduling, inventory management, shipment scheduling, demand forecasting and related tasks for all critical medical technologies (masks, tests, respirators) needed in the right quantity and at the right place. In these areas, the value proposition of $\mathrm{ML}$ applications is particularly appealing. It takes time to 
change organizations and supply chains. A huge crisis, such as the current pandemic, can produce the opportunities that will accelerate this process. It offers social and business opportunities for inventors and entrepreneurs to develop new AITs applications outside of the current core fields of applications, thereby broadening the range of applications and the allocation of capital to new industries and functions.

Overall, one can predict significant effects of the COVID-19 crisis on the rate, adoption and direction of ICTs. The effect of the crisis on other technologies, such as clean technologies, is much more ambivalent as the following section explains.

\subsection{How could the crisis affect innovation in clean technologies?}

As the COVID-19 crisis unfolds, factories shut down and workers are forced to stay at home. It seems that our planet has been given the time to catch its breath, with reports of falls in greenhouse gas emissions and atmospheric pollution. In China, during the month of February, $\mathrm{CO} 2$ emissions were down by 25 percent. However, history tells us that this respite is likely to be short term. Past economic crises have been met with increasing pollution once the economy started improving again. Worse, there is a real risk that investments to fight climate change will fall as funding becomes scarcer in a dwindling economy and as healthcare research attracts a higher share of research expenditures. However this crisis does not have to be a setback for the development of climate-friendly technologies. Policymakers could indeed decide to use the tools at their disposal, including stimulus packages, to both kick-start the economic recovery and accelerate the green transition.

The pandemic could derail plans to develop new clean technologies...

The most important negative impact of the pandemic on innovation in climate change comes from the fact that the COVID-19-induced shutdown is causing enormous economic damage. Most forecasters expect the economy to shrink this year, some even predicting a 4-percent fall in GDP-twice the fall seen after the great financial crisis of 2007-09. This incoming recession is bad news for clean technologies because recessions are historically a bad time for all investments but even more so for investments in cleantech. During the first half of 2009, new venture capital and private equity investments in clean energy companies were down 56 percent on the year before. We are already seeing some of this effect today. According to BloombergNEF, 2020 could see a fall in the amount of installed solar energy capacity for the first time in decades.

The fall in revenues caused by the crisis have sparked calls from battered industries to suspend or delay environmental regulations. China has already announced that it will modify environmental supervisions to allow firms to recover from the crisis. The pressure to weaken regulations also comes from politicians; the Czech PM unsuccessfully urged the EU to ditch the European Green Deal that aims to achieve net carbon neutrality by 2050. What's more, COVID-19 has forced countries to postpone the COP-26, the United Nations' next climate summit supposed to be held in Glasgow in November. The crisis is becoming one more hurdle in the race to get governments to agree on binding (and costly) 
emissions-reductions targets. As environmental regulations become both less stringent and more uncertain, investing in cleantech innovation becomes significantly less attractive.

Finally, containment measures have caused a sharp fall in demand for oil and gas, which caused a historic plunge in the price of a barrel of crude oil, now at its lowest since November 2002. Cheaper energy causes energy efficiency technologies, like retrofitting homes, to become less appealing. Cheaper fossil fuels also make renewable energies less profitable, further reducing the financial incentive to invest and innovate in clean energy.

\section{... but it also creates significant opportunities to accelerate the green transition}

Some observers argue that the COVID-19 crisis might lead people to revisit their lifestyle and engage less frequently in long-distance flying. However, such a change in behavior would have little impact as aviation as a whole accounts for only 2.5 percent of global emissions. Others have pointed to the fact that pandemic-related health issues may be exacerbated by pollution, which provides further incentive for governments to invest in cleaner air. That seems unlikely, as the 4.2 million deaths caused by air pollution each year in the world does little to spur governments into action.

The real opportunities lie in the policies that could be put in place to address the crisis, affecting big industries as well as investments and innovation in clean technologies. Governments are currently unveiling unprecedented stimulus packages to revive and support the economy. These vast resources, that usually go to big industries like energy, construction or transportation, could be used to encourage the development of clean technologies; including renewables, batteries and carbon capture. In 2009, Obama did just that, providing $\$ 80$ billion towards the development of clean energy technology as part of his American Recovery and Reinvestment Act. It is not yet among the priorities of the current U.S. administration. On the 27 th of March, Congress passed a record $\$ 2$ trillion economic stimulus plan, none of which was aimed at supporting renewable energies. In Europe, the EU is still discussing the details of its economic response but there are hopes for a green stimulus package. In a recent statement, the EU Council asserted that while the fight against the pandemic and its economic consequences was the priority, it should be compatible with its environmental goals. Policymakers could also decide to follow the International Energy Agency's recommendation to use low oil prices to scrape subsidies for fossil fuels consumption. Because these subsidies make cleaner industries less competitive, removing them would stimulate the development of clean technologies.

Finally, this crisis has given us a preview on what is to come with the approaching climate crisis. As explained in Section 2, health is a global public good and countries underinvested in it. When the pandemic hit, most countries were unprepared and paid the cost. This could prompt governments to better prepare for the incoming climate crisis. What's more, politicians have witnessed that their citizens are willing to sacrifice some of their economic and social well-being to address a life-threatening menace. The current crisis could therefore provide supporting evidence in favor of more ambitious public policies for the development of clean technologies. We now find ourselves at a crossroads. Whether the COVID-19 crisis derails or bolsters the green transition of our economies will depend on policymakers. 


\subsection{Changes in the organization of research: the open-science revolution}

Scientific publishing takes time. In contrast with the traditional press, scientific periodicals have a slow review process. This lag is due to the 'peer-review' process, a validation mechanism that can sometimes take years. However, with the immediacy of the online world, society demands faster and better access to information, and scientists have accelerated the call for a revised process (Gewin, 2016). One tool that has found considerable success in many fields are preprints. These consist of Open Access (free-to-read) publications that have not yet been peer-reviewed. These articles will eventually undergo the same revision process, but preprint outlets allow for quick dissemination of results (Johansson et al., 2018). Preprints have gained momentum over the years despite the concerns over quality outcomes that some attach to Open Access articles.

How did the current crisis affect the functioning of scientific research?

The current COVID-19 crisis has imposed immediacy and openness on scientists. Making science progress as quickly as possible has led researchers worldwide to adopt an unprecedented sharing policy. In the last weeks, researchers have identified and shared hundreds of viral genome sequences and

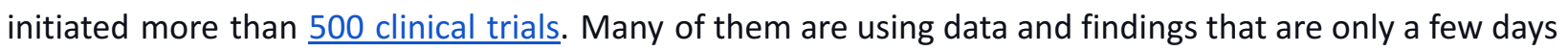
(sometimes hours) old, and their majority traces back to the first Chinese sequencing. But most importantly, a significant portion of traditional outlets have made their publications openly available for the community. ${ }^{16}$

The coronavirus has ignited the scientific community in ways no other pressing question had ever done before. The review process to separate the wheat from the chaff is as novel as it gets. Making use of crowdfunding as a community tool, a platform for online-preprint reviews has just been launched. And not only for life scientists. Other disciplines are involved too. The White House and the NIH have challenged computer scientists to develop automatic text analysis methods that help discovery from full-text corpora.

\section{What long-term effects?}

The pandemic has come to show that a different organization of science is not only possible, but socially desirable. The advantages of openness and velocity seem evident for life scientists working towards a vaccine or an antiviral. And for policymakers too. Open Access to scientific work has been possible because we already had the infrastructure to support it efficiently. It has been on the political agenda for quite some time, and early-career researchers have taken the lead in their disciplines (Farnham et al., 2017). Many funding agencies are requesting that research is made openly available, while in some countries like Switzerland, universities are even renegotiating (not without difficulty) their deals with publishers so that science is made publicly available.

One key lesson from the crisis is that concealment impedes the advancement of science, and we need a way of sharing data as efficiently as possible. The life sciences would undoubtedly benefit the most from, not just access to results, but also access to raw data in a timely, structured and interoperable manner.

\footnotetext{
${ }^{16}$ See also https://actu.epfl.ch/news/covid-19-publishers-make-online-contents-available/
} 
Despite the skepticism (e.g., Andreoli-Versbach, 2014; Longo, 2016), the current crisis could be a catalyst for the adoption of FAIR (Findable, Accessible, Interoperable and Reusable) Data Practices (EU Commission, 2018).

\section{Conclusion}

The development of drug(s) and vaccine(s) that will enable us to overcome the present crisis is justifiably the sole focus of attention these days. We have analyzed the conditions and procedures, as well as the institutional and political frameworks that could have accelerated their development. The immediate lessons in terms of science and innovation policy are rather cruel: lost time cannot be made up when it comes to science and technology. Furthermore, an intense but belated mobilization of resources aimed at specific scientific objectives will not compensate for the inadequacy of private investments and the misguided efforts of public policy that have characterized the recent period regarding vaccine R\&D. It seems to us that economic theories such as market failures (and their remedies) and the application of concepts such as the elasticity of science offer powerful tools for reflecting on STI policy questions that typify times of crisis and great societal challenges. The present report offers an attempt in this direction.

However, the assessment and prospects of the crisis with regard to STI policy cannot be limited to this urgent and compelling search for vaccines and other critical technologies. To prevent outbreaks (ex-ante) or mitigate their effects (ex-post), our society needs more than technological fixes. A second line of response is precautionary and calls for the production of knowledge of a rather different kind than what the first line of response is going to produce. It involves public health education and infrastructure and the development of specific forms of technical and organizational expertise for ex ante and ex post responses to potential pandemics. This response is about all ranges of research and innovation approaches, covering (and combining) many disciplines, allowing society to organize and inform itself collectively to cope with forced adaptations to prevent and deal with pandemics.

The current crisis is a reminder that all branches of science matter. As a society, we need to deal with all the facets of the pandemic and, therefore, we need to rely on all scientific disciplines. For example, we are convinced that economic knowledge is critical for mitigating the effects of the pandemic and for understanding the economic forces that have led to the current situation, with a view of proposing changes. But other fields of social and behavioral sciences are proving equally critical for optimizing pandemic response (Van Bavel et al. 2020).

Yet, the real and profound impact of this crisis on innovation may manifest itself at a higher level than just discussed. The system itself may change, in a way that Nobel-prize winning economist Paul Romer calls 'innovations in meta-rules,' which he defines as "the rules for changing rules". He writes : "Stable systems of rules (or meta-rules) are hard to change, even when the environment changes and they are no longer optimal, because it is extremely costly and difficult to reach consensus and coordinate change" (Romer, 2010).

The shock of this crisis will certainly help us to change several of these sets of rules. The present crisis shakes up the whole STI ecosystem and offers an opportunity to challenge established rules. It is perhaps at this level that the impact of the crisis will be most fundamental in the innovation domain. Let us mention, for instance, the disruptions of meta-rules in connection with the spatial organization of work 
or even leisure activities-disruptions that we now observe can, in turn, lead to other extremely significant changes. One concrete example is the sustainable mobility domain, following the economic shock that sectors like the low-cost aviation industry are going to endure. Let us also mention innovations in meta-rules, linked with health infrastructures and the functioning, geographical distribution and international coordination of supply chains in the realm of medical technologies. And finally, let us mention the changes that will concern the organization of science and knowledge and data sharing.

These three examples of rule changes, so difficult to achieve in normal times, illustrate the powerful leap forward that could occur in these different areas-and this may be considered a positive effect for society. This positive effect is less obvious and remains to be evaluated with regard to rule changes in the domain of law and private data protection that the explosion of electronic tracking and identification technologies may trigger. 


\section{References}

Andreoli-Versbach, P., \&Mueller-Langer, F. (2014). Open access to data: An ideal professed but not practised, Research Policy, 43(9), 1621-1633. DOI: 10.1016/j.respol.2014.04.008

Aristei, D., Sterlacchini, A., \& Venturini, F. (2017). Effectiveness of R\&D subsidies during the crisis: firm-level evidence across EU countries. Economics of Innovation and New Technology, 26(6), 554-573. DOI: $10.1080 / 10438599.2016 .1249543$

Atkins, D. (2003). Transformation through Cyberinfrastructure-based knowledge environments, in B. Kahin and D. Foray, Advancing Knowledge and the Knowledge economy, MIT Press, 2007

Azagra-Caro, J. M., Tijssen, R. J., Tur, E. M., \& Yegros-Yegros, A. (2019). University-industry scientific production and the Great Recession. Technological Forecasting and Social Change, 139, 210-220. DOI: 10.1016/j.techfore.2018.10.025

Baldwin, R., \& di Mauro, B. W. (2020). Economics in the Time of COVID-19. A VoxEU. org Book, Centre for Economic Policy Research, London. Link: https://voxeu.org/content/economics-time-covid-19

Barlevy, G. (2007). On the cyclicality of research and development. American Economic Review, 97(4), 1131-1164. DOI: 10.1257/aer.97.4.1131

Barton, J. H., \& Emanuel, E. J. (2005). The patents-based pharmaceutical development process: rationale, problems, and potential reforms. Journal of the American Medical Association, 294(16), 2075-2082. DOI: 10.1001/jama.294.16.2075.

Bloom, N., Jones, C. I., Van Reenen, J., \& Webb, M. (2020). Are ideas getting harder to find? American Economic Review, 110(4), 1104-1144. DOI: 10.1257/aer.20180338

Brautzsch, H. U., Günther, J., Loose, B., Ludwig, U., \& Nulsch, N. (2015). Can R\&D subsidies counteract the economic crisis?-Macroeconomic effects in Germany. Research Policy, 44(3), 623-633.

DOI: 10.1016/j.respol.2014.11.012

Bresnahan, T. (2019). Artificial Intelligence technologies and Aggregate Growth Prospects. Available at: https://web.stanford.edu/ tbres/Al Technologies in use.pdf

Burrone, E., Gotham, D., Gray, A., de Joncheere, K., Magrini, N., Martei, Y. M., ... \& Kieny, M. P. (2019). Patent pooling to increase access to essential medicines. Bulletin of the World Health Organization, 97(8), 575-577. DOI: 10.2471/BLT.18.229179

Cincera, M., Cozza, C., Tübke, A., \& Voigt, P. (2012). Doing R\&D or not (in a crisis), that is the question.... European planning studies, 20(9), 1525-1547. DOI: 10.1080/09654313.2012.709064

Coch, L., \& French Jr, J. R. (1948). Overcoming resistance to change. Human relations, 1(4), 512-532. DOI: $\underline{10.1177 / 001872674800100408}$

Cockburn, I. M., Stern, S., \& Zausner, J. (2011). Finding the Endless Frontier: Lessons from the Life Sciences Innovation System for Energy R\&D. In Accelerating Energy Innovation: Insights from Multiple Sectors (pp. 113-157). University of Chicago Press.

Available at: $\underline{\text { http://www.nber.org/chapters/c11749 }}$ 
Eicher, T. S. (1996). Interaction between endogenous human capital and technological change. The Review of Economic Studies, 63(1), 127-144. DOI: 10.2307/2298118

European Commission Expert Group on FAIR Data, (2018). Turning FAIR into Reality. DOI: 10.2777/1524

Fang, F. C., \& Casadevall, A. (2015). Competitive science: is competition ruining science?. Infection and Immunity. 83(4): 1229-1233. DOI: 10.1128/IAI.02939-14

Farnham, A., Kurz, C., Öztürk, M. A., Solbiati, M., Myllyntaus, O., Meekes, J., ... Hettne, K. (2017). Early career researchers want Open Science. Genome Biology, 18(1), 221.

DOI: $10.1186 / \mathrm{s} 13059-017-1351-7$

Ferretti, L., Wymant, C., Kendall, M., Zhao, L., Nurtay, A., Abeler-Dörner, L., ... \& Fraser, C. (2020). Quantifying SARS-CoV-2 transmission suggests epidemic control with digital contact tracing. Science. DOI: $10.1126 /$ science.abb6936

Foray, D., \& Lissoni, F. (2010). University research and public-private interaction. In Handbook of the Economics of Innovation (Vol. 1, pp. 275-314). North-Holland. DOI: 10.1016/S0169-7218(10)01006-3

Fredriksson, P. G., Neumayer, E., \& Ujhelyi, G. (2007). Kyoto Protocol cooperation: Does government corruption facilitate environmental lobbying?. Public Choice, 133(1-2), 231-251.DOI: $\underline{10.1007 / s 11127-007-9187-4}$

Gates, B. (2015). The next epidemic-lessons from Ebola. New England Journal of Medicine, 372(15), 1381-1384. DOI: $\underline{10.1056 / N E J M p 1502918}$

Gates, B. (2018). Innovation for pandemics. New England Journal of Medicine, 378(22), 2057-2060. DOI: $\underline{10.1056 / N E J M p 1806283}$

Gewin, V. Data sharing: An open mind on open data. Nature 529, 117-119 (2016). DOI: $10.1038 / \mathrm{nj} 7584-117 \mathrm{a}$

Hud, M., \& Hussinger, K. (2015). The impact of R\&D subsidies during the crisis. Research policy, 44(10), 1844-1855. DOI: $\underline{10.1016 / \text { i.respol.2015.06.003 }}$

Jensen, P.H. and Webster, E., (2011). Macroeconomic conditions and the determinants of commercialisation. Cambridge Journal of Economics, 35(1), 125-143. DOI: 10.1093/cje/beq012

Johansson, M. A., Reich, N. G., Meyers, L. A., \& Lipsitch, M. (2018). Preprints: An underutilized mechanism to accelerate outbreak science. PLoS Medicine, 15(4).

DOI: 10.1371/journal.pmed.1002549

Kremer, M., (2000). Creating Markets for New Vaccines Part I: Rationale. National Bureau of Economic Research Working Paper No 7716. DOI: 10.3386/w7716

Kremer, M., \& Snyder, C. M. (2015). Preventives versus treatments. The Quarterly Journal of Economics, 130(3), 1167-1239. DOI: 10.1093/qje/qjv012

Lakdawalla, D. N. (2018). Economics of the pharmaceutical industry. Journal of Economic Literature, 56(2), 397-449. DOI: 10.1257/jel.20161327 
Lewis, T. R., Reichman, J. H., \& So, A. D. (2007). The case for public funding and public oversight of clinical trials. The Economists' Voice, 4(1). DOI: 10.2202/1553-3832.1123

Longo, D. L., \& Drazen, J. M. (2016). Data Sharing. The New England Journal of Medicine, 374(3), 276. DOI: $10.1056 /$ NEJMe1516564

Merton, R. K. (1957). Priorities in scientific discovery: a chapter in the sociology of science. American sociological review, 22(6), 635-659. DOI: $\underline{10.2307 / 2089193}$

Moon, S.(2017). Powerful ideas for global access to medicines. The New England Journal of Medicine, DOI: $10.1056 /$ NEJMp1613861

Mowery, D. C. (2010). Military R\&D and innovation. In Handbook of the Economics of Innovation (Vol. 2, pp. 1219-1256). North-Holland. DOI: 10.1016/S0169-7218(10)02013-7

Myers, K. (forthcoming) The Elasticity of Science. American Economic Journal: Applied Economics. DOI: 10.1257/app.20180518

Olson, G., \& Olson, J. (2003). Mitigating the effects of distance on collaborative intellectual network. Economics of Innovation and New Technology, 12(1), 27-42. DOI: 10.1080/10438590303117.

Patti, A. L., Gilbert, J. P., \& Hartman, S. (1997). Physical co-location and the success of new product development projects. Engineering Management Journal, 9(3), 31-38.

DOI: $\underline{10.1080 / 10429247.1997 .11414949}$

Roberts, P. W. (1999). Product innovation, product-market competition and persistent profitability in the US pharmaceutical industry. Strategic Management Journal, 20(7), 655-670.

DOI: $10.1002 /(\mathrm{SICl}) 1097-0266(199907)$

Romer, P. (2010). What parts of globalization matter for catch-up growth? American Economic Review, P\&P, 100(2), 94-98. DOI: 10.1257/aer.100.2.94

Rosenberg, N. (1992). Economic experiments. Industrial and Corporate Change, 1(1), 181-203. DOI: $10.1093 / \mathrm{icc} / 1.1 .181$

Sampat, B.., (2012). Mission-oriented biomedical research at NIH. Research Policy,41(10), 1729-1741 DOI: $\underline{10.1016 / \text { i.respol.2012.05.013 }}$

Sarewitz, D., \& Nelson, R. (2008). Three rules for technological fixes. Nature, 456(18), 871-872. DOI: $10.1038 / 456871 a$.

Scherer, F. M. (2010). Pharmaceutical innovation. In Handbook of the Economics of Innovation (Vol. 1, pp. 539-574). North-Holland. DOI: 10.1016/S0169-7218(10)01012-9

Scotchmer, S. (2004). Innovation and Incentives. MIT press.

Stephan, P. E. (2012). How economics shapes science (Vol. 1). Cambridge, MA: Harvard University Press.

Van Bavel, J. J., Boggio, P., Capraro, V., Cichocka, A., Cikara, M., Crockett, M., ... \& Ellemers, N. (2020). Using social and behavioural science to support COVID-19 pandemic response. Available at PsyArXiv. DOI: $10.31234 /$ osf.io/y38m9. 
Van den Hove, S., Le Menestrel, M., \& De Bettignies, H. C. (2002). The oil industry and climate change: strategies and ethical dilemmas. Climate Policy, 2(1), 3-18. DOI: 10.3763/cpol.2002.0202.

Wang, L. X. (2019). Global drug diffusion and innovation with a patent pool: The case of HIV drug cocktails. Available at SSRN 3426554. DOI: 10.2139/ssrn.3426554. 